\title{
Student's Perceptions of Automotive Engineering Study of Yogyakarta State University on Online Learning During the Pandemic Covid-19
}

\author{
I Setiawan ${ }^{1}$, I Nurhayati ${ }^{2}$, and Marzuki ${ }^{3}$ \\ \{ikhtiyarsetiawan.2019@student.uny.ac.id ${ }^{1}$,iffah_nurhayati@uny.ac.id², \& marzuki@uny.ac.id³ $\}$ \\ ${ }^{1}{ }^{\prime}{ }^{\prime}$ Department of Civic Education, Graduate School of Universitas Negeri Yogyakarta, Sleman, \\ Special Region of Yogyakarta, 55281, Indonesia.
}

\begin{abstract}
This research was conducted on students of Class C Automotive Engineering Study Program at Yogyakarta State University. The purpose of this study was to determine the perception of students of the Class C Automotive Engineering Study Program at UNY towards online lectures during the pandemic Covid-19. This study uses a descriptive analysis method, namely to examine the perceptions of students of the Class C Automotive Engineering Study Program at UNY regarding the online learning process during the pandemic Covid-19. The results of this study indicate that students of the Automotive Engineering Study Program class C at UNY feel less effective and dissatisfied with online learning with various existing problems. However, using a good learning model can deal with existing obstacles, the right and appropriate communication model and learning style will lead to the success of online learning.
\end{abstract}

Keywords: Perception; Learning model; Covid-19.

\section{Introduction}

Education has the meaning of conscious effort to prepare and form learners through guidance, teaching, and training activities for their role in the future. Education has an important role in helping learners achieve the knowledge and skills needed to grow and innovate to achieve targeted goals. Recognizing the importance of education, the Government formulated the National Education Goals in Law No. 2 of 1989. Learning is the main thing in education that implements it continuously. Education is a planned effort to realize learning activities and learning processes for students to develop their potential and the skills they need in the society, nation and state.

Along with the increasing number of positive Covid-19 in Indonesian. The Indonesian Ministry of Education and Culture issued Circular Letter No. 3 of 2020 concerning Prevention of Covid-19 in education units. The pandemic Covid-19 has had a huge impact on various sectors and one of them is the education sector. The crisis really came suddenly, governments in any hemisphere including Indonesian had to make a decision to close schools in order to reduce the spread of the Covid-19 virus. On March 24, 2020, The Minister of Education and Culture of The Indonesian state issued Circular Letter Number 4of 2020 regarding the learning process in the Covid-19 spread period which instructs that the learning process be carried out at home through online learning. 
The Covid-19 outbreak requires distance learning that has almost never been done simultaneously for all elements of education, namely learners, teachers to parents. This online learning program has been implemented at the Indonesian education level to the university level. Following up on the advice of the Indonesian Ministry of Education and Culture's advice regarding the implementation of learning activities during the pandemic Covid-19, the Rector of Yogyakarta State University (UNY) eliminated conventional learning activities and replaced them with a distance learning system.

Online learning is a national policy as the main step in efforts to stop the spread of the Covid-19 in Indonesian. Online learning trends have occurred around the world during Covid19. This presents a challenge for all parties involved the fields of education. With the government's recommendation, learning is done from home by using the internet. In the advancement of information technology in the era of 4.0 that is so fast can help facilitate in continuity when doing online lectures. Observing the effectiveness in online learning automotive engineering students in Yogyakarta State University, online learning has a different technicality from the face-to-face system learning model with online learning. Online lectures can help educators and students determine communication patterns in implementation learning.

Online learning activities in lectures conducted in real time make educators choose the right application for continuity during the learning process. In this case, some colleges use policies in the use of distingtive applications. Use universal apps like Zoom, Edmodo, Whattsapp (WA), Youtube, Flickr, Twitter, Instagram, and Webblog. Generally students think that applications that are easy in their optimization and save quotas are more effective in supporting online learning. But in its implementation, it does not rule out the possibility that there can be some obstacles. The problems that arise and the carrying capacity in carrying out online treatment experienced by students make learning ineffective. Problems that occur include the lack of networking, home atmosphere and unsannportive environment also determine the effectiveness of online learning. The biggest difficulty faced by students is concerned with understanding the material, because the learning style in each student affects the level of understanding in the acceptance of learning materials. Mentioned that full online learning is considered not possible for face-to-face, so all needs cannot be accommodated for learning needs.

This research is devoted to students Automotive Engineering Study Program class C at Yogyakarta State University which in the learning process does not depend on the delivery made by the lecturers, but also needs to be carried out discussions and presentations of assignments by students. With the continued learning process online, some materials that should be done interactively are sometimes constrained by technical problems related to mobile networks. With these constraints, students' perception of the effectiveness of online lectures that lead to learning models with a learning media approach, communication model, and learning process in students of Automotive Engineering Study Program of Yogyakarta State University can determine success in the learning process. With this, the author examined the perception of students of automotive engineering study program class C at Yogyakarta State University to the online lecture system during the pandemic Covid-19.

\section{Method}

This study uses a descriptive analysis method, namely to examine the perceptions of students of the Automotive Engineering Study Program at Yogyakarta State University 
regarding the online learning during the pandemic Covid-19 that was implemented by the Yogyakarta State University. The online learning model can be identified through several approaches, such as online learning application, communication models during learning, and the effectiveness of online learning. Data obtained from observations in the form of giving an online questionnaire. The samples involved were students of the Class C Automotive Engineering Study Program at Yogyakarta State University as respondents in this study. Determination of respondents as a sample is done by using the probability method with a stratified random sampling approach.

\section{Result}

Here are the percentage results of the perception of students of the Automotive Engineering Study Program class C at UNY towards online lectures during the pandemic Covid-19:

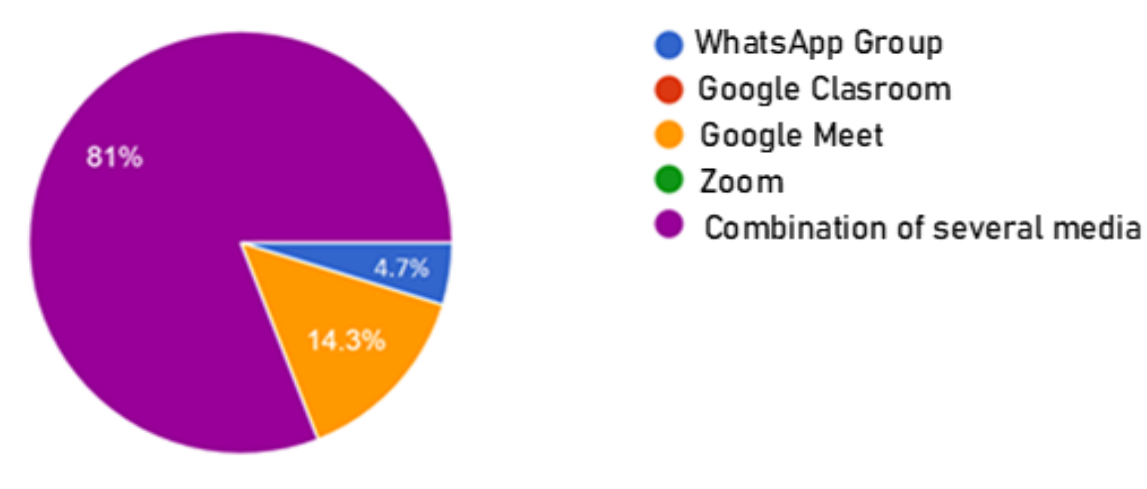

Fig. 1. Presentation of The Effectiveness of Application Media for Online Learning

The circle diagram above shows the effectiveness of application media for online lectures during the pandemic Covid-19. From the percentage of use of application media to carry out learning in lectures, students prefer the use of application media combined with other application media with a percentage of $81 \%$, using Google Meet as much as $14.3 \%$, and $4.7 \%$ choose to use WhatsApp Group. With the selection of media applications the combination of several effective media certainly has obstacles in its optimization, so it can hamper the learning process. And the obstacles that are often experienced are as follows: 


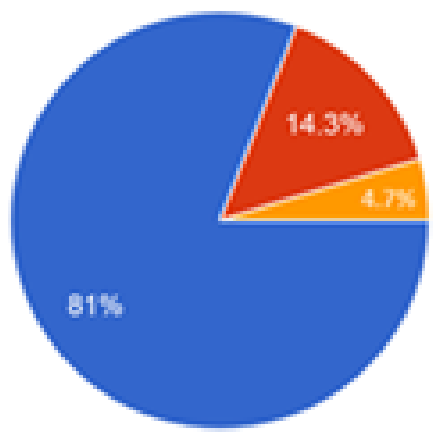

\author{
- Internet Network \\ Internet Data Quota \\ Platform System Operation
}

Fig. 2. Perception of Constraints in The Use of Application Media

The percentage in the circle diagram above shows some of the obstacles that arise when running online learning experienced by students of automotive engineering study program class $\mathrm{C}$ at UNY during the pandemic Covid-19. Constraints of useing this application can interfere during the learning process. Obstacles are often experienced when learning in using application media that shows $81 \%$ of students choose the internet network, $14.3 \%$ choose internet data quota, and $4.7 \%$ choose optimization on the platform system in the effectiveness of lectures.

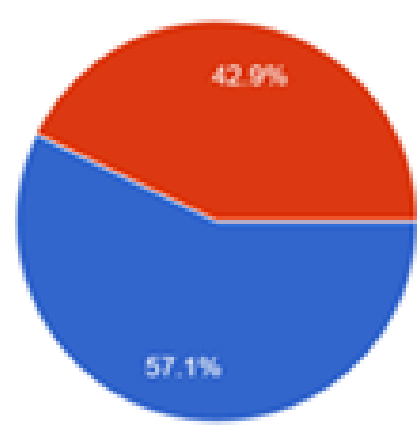

Permission to lecturer of the Relevant Subject - Trying to Find Internet Network

Not Attending Lectures

Fig. 3. Perception of constraints

The circle diagram above shows how students of the Automotive Engineering Study Program class $\mathrm{C}$ at UNY in dealing with obstacles when using application during the pandemic Covid-19. To solve problems that are scattered unexpected things can interfere with the process in learning in lectures, where each student has his own way to overcome the existing obstacles. Percentage results showed that $57.1 \%$ of students chose permission to teacher of the related courses, and $42.9 \%$ of students chose to go looking for the internet network to be able to follow the learning process. 

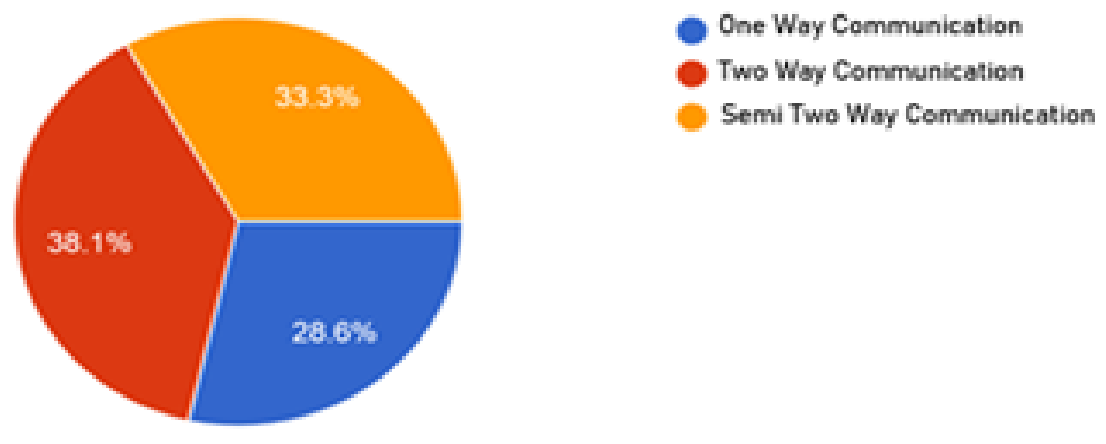

Fig. 4. Perception of Communication Model

The circle diagram above shows the type of communication model in learning that occurred in students of the Automotive Engineering Study Program class $C$ at UNY during the pandemic Covid-19. This communication model can determine how to interact in online learning process of students and lecturers. The above perception results show that $38.1 \%$ of students think that communication occurs in two-way communication, $33.3 \%$ of students think semi-two-way communication, and $28.6 \%$ of students think that communication that occurs is one-way communication in learning process.
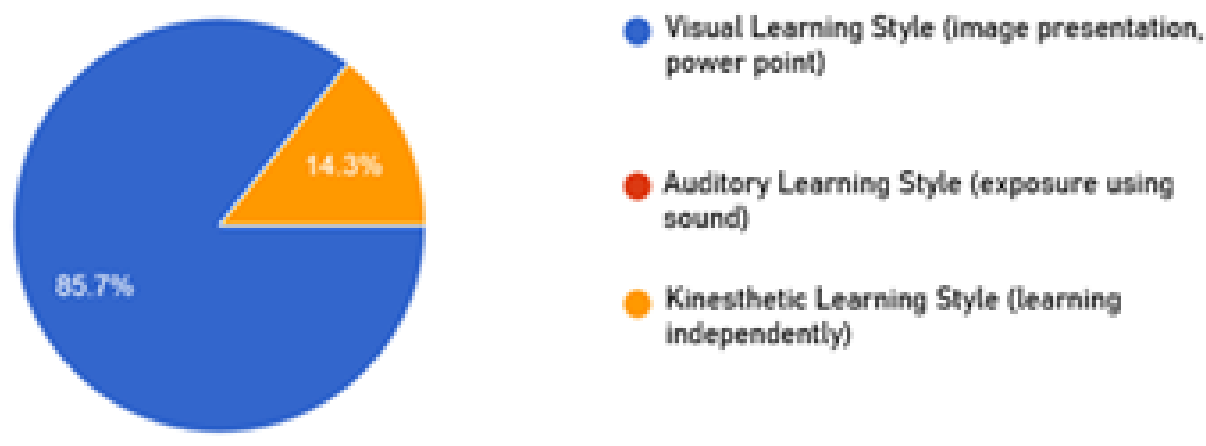

Fig. 5. Perception of Learn Style

The circle diagram above shows the learning style that is easily understood by students of the Automotive Engineering Study Program class C at UNY during the pandemic Covid-19. Learning style is the understanding of each individual in understanding each learning material. In this case lecturers not only provide material in the form of one type of learning style, but can be several types of learning styles to students. Percentage results showed that $85.7 \%$ of students chose the learning style visually, and $14.3 \%$ of students chose the learning style kinesthetically. 


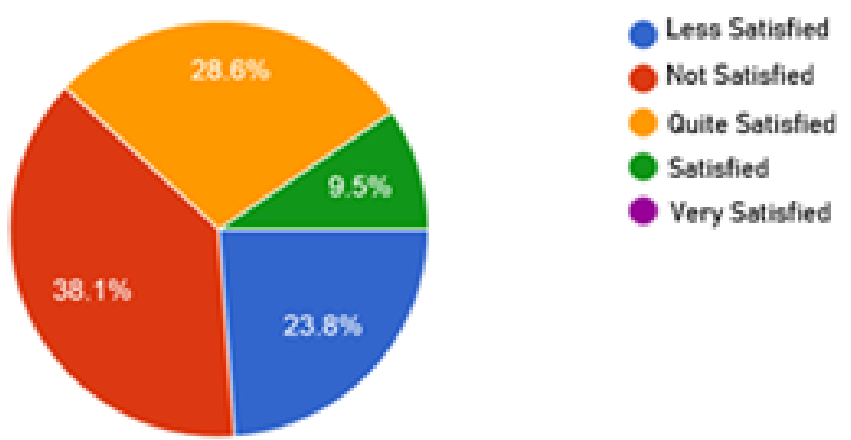

Fig. 6. Effectiveness of Online Lectures

In the circle diagram above shows the percentage of effectiveness of lectures using online application media for students of Automotive Engineering Study Program class C at UNY. Percentage results showed that $38.1 \%$ of students not satisfied, $28.6 \%$ of students quite satisfied, $23.8 \%$ of students are less satisfied, and $9.5 \%$ of students satisfied.

The effectiveness of lectures conducted online is influenced by the use of application media that there can be obstacles in its optimization, but in the constraints students can follow it in various ways. With the selection of communication models in learning can determine the direction of learning style for students so as to make online lectures run effectively and smoothly.

\section{Discussion}

From the results of the study obtained data that give overview the online learning model of students automotive engineering study program class C at UNY. The results showed by gives online question, it could describe the perception of students Automotive Engineering Study Program class $\mathrm{C}$ at UNY. The teaching and learning process studied is learning that on carried out online to avoid the Covid-19 virus, contained in the circular issued by the Minister of Education No. 3 of 2020 on the prevention Covid-19 virus that instructs the learning process is implemented at home with online/distance learning. This program is very appropriate to be implemented in the era of the spread on Covid-19 virus where lecturers socialize to carry out physical and social distancing.

As we know today, Indonesian is even the world in the land of the Covid-19 pandemic. The Covid-19 virus is new the name given by the World Health Organization (WHO) to patients who were infected with the corona virus which was first reported from the city of Wuhan. The pandemic outbreak came suddenly, the Indonesian government had to take the tough decision to close all schools to reduce the spread of the virus massively and to save eveyone's lives. Online lectures a solution to respond to the challenges that are present during the pandemic in education at Indonesian today. Its application is done by way of the delivery of material done over the internet synchronously or asynchronously. This makes it easier for students who follow online courses to save more time and energy. This perception leads to learning models obtained 
from several approaches, application media in online learning, then there are obstacles in the use of application media, overcome the obstacles that arise, learn communication models, learn styles, and the effectiveness in online lectures.

With the learning done online, of course, many things must be prepared ranging from facilities and infrastructure to the readiness of universities to run the learning process online. Online learning that is done by each lecturer certainly has each way to convey the learn process in lecture. The learning process, of course, many media applications are available for use including Zoom, Whattsapp (WA), Google Classroom, Google Meet, etc. Knowledge of the application media used can determine against students to be able or not in applying learning media.

From a wide range of application media for learning in research (Figure 1) it was produced that $81 \%$ of the 48 students who were in the C-class Automotive Engineering Study Program at UNY chose a combination of several application media as the most effective application media as a learning medium during online lectures, in addition $14.3 \%$ chose Google Meet, and $4.7 \%$ used WhatsApp Group. The percentage of $81 \%$ indicates that students who choose to use combination media applications (WA, Zoom, Google Clasroom, Google Meet) as learning media applications that are effective during lectures. Information and communication technology in the field of education that is able to digitize the contents of the teaching and learning systems or more popularly called LMS (Learning Management System). Combining applications from several media to support learning is a form utilization in advancement of Information and Communication Technology the presents a new way in the process of distribution of science has changed the role of a teacher in learning process. This term is used to describe learning situations that echo several methods of delivery that aim to provide the most effective and efficient experience. Learning is not enough just by face-to-face meetings, the teaching materials provided can be visualized making it easier to learn it.

Online lectures are a means of learning in lieu of face-to-face lectures, which when in learning will certainly find obstacles in the use of application media. Online learning a form conventional learn delivery to poured into digital formats over the internet which is one of the solutions in the current pandemic emergency. In the selection of various application media to support learning will certainly bring its own obstacles for online learning. These obstacles become important things that must be resolved for smooth learning. Psychological factors originating from outside the student affect learning activities. From the results of the research questionnaire on (Figure 2) showed that as many as $81 \%$ of students experienced internet network constraints when optimizing application media at the time of learning, $14.3 \%$ on internet data quotas, and $4.7 \%$ on the optimization of platform systems. A percentage of $81 \%$ indicated that the most obstacles that appeared were on the student internet network. The results of research from respondents, the seen in general a obstacles they experience are fundamental or fundamental, including problems with the internet networks. Most students do not live in urban areas, so the type of provider they use is certainly different and the quality of many internet networks is not so much less supportive of online learning. The advancement of a technology must certainly be supported by a finger that is easy, especially on the internet network, so that in the use of technology in learning can help the learning process.

Students has getting used to online lectures, so that in the online survey questionnaire on (Figure 3) can be known how students deal with the obstacles that arise during online lectures is $57.1 \%$ with permission to lecturers related courses, and another way to follow is to go looking for the internet network as much as $42.9 \%$. Students that is a generation Z, cognitive skills and attitudes do not have significant problems in pursuing the online learning. Good communication also affects the online learning process, so the communication model also has a significant 
impact. In the implementation of virtual system lectures, the right communication model is needed. From the results of the research questionnaire on (Figure 4) showed as many as $38.1 \%$ of students felt that the communication that occurred was two-way communication, $33.3 \%$ of communication that occurred was semi-two-collar communication, and $28.6 \%$ one-way communication. From the results of the percentage shows that each student has a different learning style each individual that will affect the person in understanding something.

Good communication in learning will certainly shape the learning style that occurs, such as the results of an online survey in (Figure 5) found that $85.7 \%$ of students like the style of learning that is done visually (exposure of material using image media, PPT, word), and 14.3\% like kinesthetic learning style (learning by searching for material independently). Effectiveness in learning style will certainly determine its own sense of satisfaction in running online lectures in this pandemic. Online learning is technology-based learning that includes use the internet and other things such as in produce materials for learning, teaching, and organizing learning. Of course, each individual student will vary in the level of satisfaction when learning is carried out online, such as the results of research on (Figure 6) in the effectiveness of online lectures of students of Automotive Engineering Study Program class C at UNY as many as 38.1\% choose not satisfied in doing online learning, $28.6 \%$ are quite satisfied, $23.8 \%$ are less satisfied, and $9.5 \%$ are satisfied. With the current pandemic Covid-19 situation required to know the crowd and reduce direct interaction, online lectures are a solution. On the other hand, the implementation of online lectures conducted by each lecturer of related courses will certainly be different in the use of application media and of course there are obstacles that will arise. The longer the online lectures, the more students know how to overcome the obstacles that arise in each learning. With this, learning will be effective if from the selected learning model is right and uses a good communication model, as well as the right learning style.

\section{Conclusion}

From the results of data processing showed that 22 students of the Automotive Engineering Study Program class C at UNY assessed the effectiveness of online learning in terms of communication models with the application media use approach for learning, students prefer a combination of application media from several applications (Whatsapp, Google Clasroom, Meet, Zoom) which is considered to help for receive materials and implement a studying. The optimization of application media certainly has existing obstacles, and the obstacles that often appear are on the internet network. To deal with existing obstacles, most students will permit lecturers related courses to communicate existing problems. In communicating using learning application media, communication is often used, namely two-way communication. Automotive Engineering Study Program students prefer a visual learning style which is usually in the presentation of material using the form of images, power points, and words. The effectiveness of online learning makes it dissatisfied for some students, because it depends on the ability and motivation to learn. But by using learning models such as application media selection, can deal with existing constraints, communication models and appropriate learning styles will lead to the success of online learning.

\section{Acknowledgements}

The researchers would like to express their gratitude for the completion of this research to all my fellow students of the class of 2020 from the Class C automotive engineering study program, Yogyakarta State University who have been willing and supportive of researchers in 
conducting research. The researchers also thank the lecturers for all their guidance and support to complete this research.

\section{References}

[1] Agusmanto H. Kendala pembelajaran daring selama masa pandemi di kalangan mahasiswa pendidikan matematika: kajian kualiatatif deskriptif. Journal of Mathematics Education and Applied. 2020; 2(1):45.

[2] Budi, Brian N. Pengembangan metode pembelajaran online berbasis e-learning. Jurnal Sains Terapan. 2012; 2(1).

[3] Diah H, Dwi RH, Fathiyah I, Erlina B, Heidy A. Corona Virus Disease 2019. Jurnal Respirologi Indonesia. 2020; 40(2).

[4] Eko K, Rayandra A. Pengembangan model pembelajaran blended learning pada aspek learning design dengan platform media sosial online sebagai pendukung perkuliahan mahasiswa. Repository Unja. 2017.

[5] Hoeda M. Learning is easy. Edition 1. Jakarta. PT Elex Media Komputindo. 2013.

[6] Ida F, Risa R, Riri A, Imelda H. Pembelajaran kimia sistem daring di masa pandemi Covid-19 bagi generasi z. UIN Sunan Gunung Djati. 2020.

[7] Jeffry H, Siska DF, Winarti, Indah SB, Nur K, Viyanti. Pembelajaran sains di era akselerasi digital. Edition 1. Magetan. CV. AE MEDIA GRAFIKA. 2020.

[8] Karen G. The covid-19 pandemic: technology use to support the wellbeing of children. Journal of Pediatric Nursing. 2020; hlm 3-5.

[9] Kuntum AI, Siti KB. Rancangan pengembangan instrumen penilaian pembelajaran berbasis daring. Jurnal IPTEK. 2019; Vol. 5. hlm 31-47.

[10] Litao S, Yongming T, Wei Z. Corona virus pushed education online. Nature materials. 2020; Vol. 68.

[11] Muhammad K. A model for upgrading teachers' competence on operating computer as assistant of instruction. Global Journal of Human-Social Science: G Linguistic \& Education. 2014; 14(5).

[12] Muhibbin S. Psikologi belajar. Jakarta. PT. Grafindo Persada. 2003.

[13] Nazime T, Huseyin U, Necmettin T. Students evaluation of edu 2.0: a case study. Journal of Procedia - Social and Behavioral Sciences. 2011; Vol. 28. hlm 948-956.

[14] Siti I, Hasbullah. Blended learning, trend strategi pembelajaran masa depan. Jurnal Elemen. 2015; $1(1): 49-56$.

[15] Valentina A, Nelly A. The role of e-learning, advantages and disadvantages of its adoption in higher education. International Journal of Instructional Technology and Distance Learning. 2015; 12(1):29-42.

[16] Wim P. Pemanfaatan e-learning sebagai pendukung kegiatan belajar-mengajar Universitas Terbuka di Indonesia: studi perangkat lunak. FMIPA UGM. 2007.

[17] Yongmei B, Habte S, Anjali S. Design and evaluation of student-focused elearning. Electronic Journal of E-learning. 2012; 10(1):1-12.

[18] Yoris M. Preparing prospective teachers in integrating science and local wisdom through practicing open inquiry. Journal of Turkish Science Education.2016; 13(2): 3-14.

[19] Kemdikbud. Pusat pendidikan dan pelatihan pegawai kementerian dan kebudayaan. 2020.

[20] Undang-Undang No. 20 Tahun 2003 Tentang sistem pendidikan nasional.

[21] Undang-Undang No. 2 Tahun 1989 Tentang tujuan pendidikan nasional. 